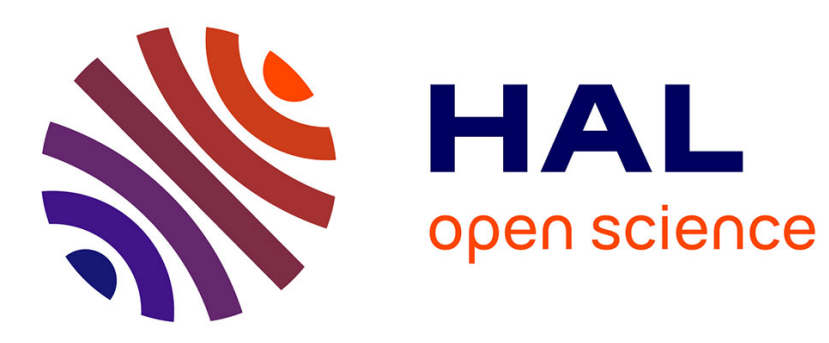

\title{
Ticks and tick-borne diseases
}

Nathalie Boulanger, Pierre Boyer, E Talagrand-Reboul, Yves Hansmann

\section{To cite this version:}

Nathalie Boulanger, Pierre Boyer, E Talagrand-Reboul, Yves Hansmann. Ticks and tick-borne diseases. Médecine et Maladies Infectieuses, 2019, 49 (2), pp.87-97. 10.1016/j.medmal.2019.01.007. hal-02496364

\section{HAL Id: hal-02496364 \\ https://hal.science/hal-02496364}

Submitted on 22 Oct 2021

HAL is a multi-disciplinary open access archive for the deposit and dissemination of scientific research documents, whether they are published or not. The documents may come from teaching and research institutions in France or abroad, or from public or private research centers.
L'archive ouverte pluridisciplinaire HAL, est destinée au dépôt et à la diffusion de documents scientifiques de niveau recherche, publiés ou non, émanant des établissements d'enseignement et de recherche français ou étrangers, des laboratoires publics ou privés.

\section{(c) (1) $\$$}

Distributed under a Creative Commons Attribution - NonCommercial| 4.0 International 


\section{TIQUES ET MALADIES VECTORIELLES À TIQUES}

\section{TICKS AND TICK-BORNE DISEASES}

\section{Nathalie Boulanger ${ }^{a^{*}}$, Pierre Boyer ${ }^{a}$, Emilie Talagrand-Reboul ${ }^{a}$, Yves Hansmann ${ }^{b}$}

a EA 7290 : virulence bactérienne précoce, groupe Borréliose de LYme. Université de Strasbourg. Membre du Centre National de Référence Borrelia - France

${ }^{\text {b }}$ Service des maladies infectieuses et tropicales, Hôpitaux Universitaires de Strasbourg, Fédération de Médecine translationnelle de Strasbourg, Membre du groupe ESGBOR de I'ESCMID.

*Corresponding author: nboulanger@unistra.fr

Mots clés : tiques, Ixodes, maladies à tiques, Lyme, anthropisation

Keywords: ticks, Ixodes, tick-borne diseases, Lyme, anthropization 


\section{Résumé}

Les tiques représentent des acteurs majeurs dans les maladies à transmission vectorielle, tant par la diversité des agents infectieux transmis que par leur impact en santé humaine et animale, et leur impact socio-économique surtout dans les pays de l'hémisphère sud. En Europe, les tiques Ixodes sont les vecteurs les plus importants sur le plan sanitaire, compte tenu de leur large répartition dans les écosystèmes et des différents agents infectieux transmis, parmi lesquels les bactéries du genre Borrelia, responsables de la borréliose de Lyme, et le virus de l'encéphalite à tique.

L'augmentation de ces tiques dans l'environnement est indéniable depuis le début du XXème siècle, du fait des modifications majeures apportées par l'homme sur la biodiversité. La sensibilisation du personnel médical et du grand public fait partie des actions essentielles pour mieux contrôler ces infections transmises par les tiques. « Mieux les connaître pour mieux s'en protéger » constitue donc une approche simple, mais efficace compte tenu de leur présence ubiquiste dans notre environnement et du mode particulier de transmission des agents infectieux qu'elles sont susceptibles d'héberger (repas sanguin long le plus souvent et délai de transmission variable pour les bactéries, virus et parasites). Enfin, en tant qu'ectoparasites, les tiques sont aussi susceptibles de provoquer des nuisances plus ou moins importantes par la composition spécifique de leur salive, tant chez l'homme que chez l'animal. 


\section{Abstract}

Ticks are a major group of arthropod vectors, characterized by the diversity of pathogens they transmit, by their impact on human and animal health, and by their socioeconomic implication especially in countries of the Southern Hemisphere. In Europe, Ixodes is the most important tick due to its wide distribution in the ecosystems and the variety of transmitted pathogens, in particular Borrelia (responsible for Lyme borreliosis), but also the tick-borne encephalitis virus.

Their increased presence in the environment since the beginning of the $20^{\text {th }}$ century is undeniable, because of major modifications in the biodiversity caused by humans. Increasing the awareness of health professionals and the general population is required to achieve better control of these infections. Thus, "a better understanding of these tick-borne diseases for a better control" is a simple but effective approach, considering their ubiquity in the environment and their particular mode of pathogen transmission (long-lasting blood meal for hard ticks and delayed transmission for bacteria and parasites). Finally, these ectoparasites are problematic due to the potential allergic reactions and other damages caused by their saliva, in humans and animals. 


\section{Ticks}

Ticks are present worldwide and, depending on species, they may be observed in highly varied habitats, from the driest to the most humid. Ticks are acarines that may be distinguished from insects by the absence of segmented body and by their spherical form. A total of 900 species of ticks have been identified. They are mainly divided into two families: hard ticks or Ixodidae and soft ticks or Argasidae. A third family has been identified, i.e. Nuttalliellidae, but it is only made of one species: Nuttalliella namaqua [1]. This species is rarely observed and will thus not be referred to in the present article. A total of 193 species are part of the Argasidae family, mainly as two major genera: Argas and Ornithodoros. Almost 700 species are part of the Ixodidae family, and they are divided into seven genera. The main genera are: Amblyomma, Dermacentor, Haemaphysalis, Hyalomma, Ixodes, and Rhipicephalus. In France the most frequent genera are Ixodes (widely prevalent), Dermacentor, and Rhipicephalus for hard ticks, and the Argas genus for soft ticks (Figure 1).

\subsection{Tick morphology}

Ticks are large acarines (several millimeters long) with a non-segmented body or idiosome (merged prosoma [or thorax] and opisthosoma [or abdomen]), four pairs of legs in nymphs and adults, and three pairs of legs in larvae. Hard ticks have a hard dorsal scutum covering one third of their body, except for males as their entire body is covered by the scutum. This is why male hard ticks ingest small quantities of blood or no blood at all. Soft ticks do not have any scutellum. Their tegument looks like crumpled leather. The feeding structure of hard ticks is located in front of the head; it is quite large for Ixodes ticks and smaller for other hard ticks. Soft ticks have a very small and barely visible feeding structure located on the underside of the body or sub-terminal part of their body.

\subsection{The various stages of development}


Ticks go through four development stages: eggs, larvae, nymphs, and male/female adults. Blood must be ingested in-between each stage to induce molting. Ticks are thus hematophagous at all stages.

Female hard ticks drop off their vertebrate host after the blood meal, to lay thousands of eggs in the vegetation and die. Ixodes male ticks (Prostriata) do not feed, but they can be found on a host when they need to breed. Males of other hard ticks (Metastriata) can feed, but only very small quantities of blood (twice their weight). Most of these ticks feed on three different hosts and drop off on the ground between each stage to molt (three-host cycle, most ticks). For two-host cycles, larvae and nymphs stay on the same host and for one-host cycles, the whole life cycle of the tick occurs on one animal [2].

Soft ticks have several nymphal stages (between two and eight); ticks feed on blood inbetween each nymphal stage. Both males and females feed, and females lay a few hundred eggs after each blood meal. A blood meal lasts approximately 15 to 30 minutes, except for larvae as they can feed for up to several days [2]. This is why soft ticks are very rarely observed on patients, but rather in their habitats.

\subsection{The blood meal}

Ticks are all strictly hematophagous. Looking for hosts to feed on is therefore essential for their survival. They have developed a highly complex detection system (sensory bristles, pedipalps, Haller's organ on front legs) to detect hosts, mainly wild animals. Humans are accidental hosts. Ticks end up biting humans when they visit the tick's habitat. Conversely, mosquitoes come into the human habitat. These differences are associated with highly different prevention and vector control measures, which will be addressed later on. The blood meal is long in hard ticks, i.e. between 3 and 10 hours depending on the development stage, and tick bites rather occur during the day. Female adults may ingest blood amounts equivalent to up to 100 times their weight. However, later-stage soft ticks (nymphs and adults) only feed for a few minutes and bites rather occur at night. 


\subsection{Tick bite and saliva}

The tick bite mechanism is particularly sophisticated. After finding a warm and humid spot on the skin, ticks pierce the epidermis with their sharp blades (chelicerates) and settle with their denticulated harpoon (hypostome). Ticks then secretes a cement-like substance that keeps them firmly attached to the skin and prevents premature dropping off. An inoculation compartment is formed around the feeding structures, followed by an hemorrhage. The role of tick saliva has extensively been studied and most involved molecules have been identified, mainly in hard ticks because of the long duration of their blood meals. Saliva has a pharmacological action on the host (coagulation and pain inhibition, etc.) but it also inhibits the host's local immune responses through immunosuppressive properties targeting various skin cells [3]. Tick saliva may cause allergic reactions in some hosts, either by inducing an immediate reaction at the bite site - that should be distinguished from erythema migrans observed with Lyme borreliosis - or leading to ascending paralysis mainly observed with Ixodes tick saliva [4]. More than $70 \%$ of tick bites in adults occur on the legs [5].

Saliva of Argas soft ticks is also known to induce an anaphylactic shock in susceptible individuals [6]. Cross allergy to red meat, tick saliva, and an anti-cancer drug (cetuximab) has recently been reported in Australia, the United States, and Europe. This cross allergy is associated with a reaction to galactose-alpha [7].

\section{Ticks of medical interest in France}

Various works on ticks were initiated by French entomologists, such as Gilot, Beaucournu, Guigen, and Perez to only name a few $[8,9]$. Studies thus started to be performed well before the 2016 French national plan on Lyme disease [10].

Approximately 40 species of ticks are currently identified in France. The present article only focuses on the most frequent in humans and on those that may pose public health problems. Considering the 
major environmental changes made by humans since the start of the $20^{\text {th }}$ century, Ixodes ticks now live in anthropogenic forest ecosystems where ticks' favorite wild animals proliferate. All ecosystems are affected, even those located in urban and suburban areas where Ixodes ticks may be found $[11,12]$.

\subsection{Ixodes ricinus}

I. ricinus ticks are the most prevalent ticks in France, except around the Mediterranean basin as the climate is too dry. I. ricinus ticks are also observed in central Corsica because of a humid and continental climate. In continental climates, diapause is observed in I. ricinus ticks during winter and they are usually active from March to October depending on climatic conditions. In oceanic climates, I. ricinus ticks are active almost all year round. Most ticks wait for their host, in a position known as "questing", on the tips of grasses and leaves (Figure 2). Highly susceptible to desiccation, Ixodes ticks drop off the host on a regular basis to rehydrate on the ground. They are able to climb, up to onemeter high, and to come down on vegetation. They, however, never fall from trees. Ixodes ticks are ubiquitous and can feed from more than 300 hosts: small and large mammals, reptiles, birds (Figure 1) [13].

\subsection{Dermacentor reticulatus and D. marginatus}

Adult Dermacentor reticulatus and D. marginatus ticks are mainly found on humans, and nymphs and larvae are found in animals' hutches. They have short feeding structures and their cuticle is marbled (Figure 1). D. marginatus ticks are particularly prevalent around the Mediterranean basin. They are thermophilic ticks, commonly found in open areas such as clearings, but also in forests. D. reticulatus ticks are more frequently observed in continental climates. They are commonly found on dogs and sheep ungulates. They can also be found on humans, most often with bites on the scalp [14]. Adultstage ticks are also questing ticks, just like Ixodes ticks (Figure 2). 


\subsection{Rhipicephalus sanguineus}

This species of ticks is mainly observed in dogs (Figure 1). They are endophilic ticks found in doghouses, kennels, outside walls of houses or even inside houses. These ticks can bite humans at all stages. They have short feeding structures. $R$. sanguineus is mainly prevalent in warm weather regions with mild winters [14].

\subsection{Argas reflexus}

Argas reflexus ticks usually feed on pigeons (Figure 1). They can bite humans when their usual host is not available. In that case, they leave the pigeons' nest and come into houses where they bite humans at night during short blood meals. In urban areas they are most commonly found in attic flats, close to pigeons; in rural areas houses close to dovecotes are affected [8]. A. reflexus bites may be responsible for major allergic reactions to their saliva, that may even trigger an anaphylactic shock. These ticks have never been proven responsible for the transmission of infectious agents to humans.

\section{Tick-borne diseases}

Ticks are the most important vectors of vector-borne diseases in terms of human and animal health [15]; they come first before mosquitoes which are in first position in terms of human health with malaria, dengue, etc. Ticks are responsible for the transmission of many infectious agents: bacteria (Borrelia, Anaplasma, etc.), viruses (tick-borne encephalitis), and even parasites (Babesia, Theileria) (Table 1). Pathologies associated with these infectious agents are mostly zoonoses for which humans are accidental hosts and represent a dead-end for the infectious agent. The host acquires the infectious agent in tick-infested habitats. Transmission usually occurs through hematophagous bites, but also through exposure to bodily fluids infected with tularemia or through blood transfusions for Babesia spp., etc. [16]. The pathogen may persist for a long time in ticks because it can be transmitted from stage to stage (transstadial transmission), from females to eggs (vertical 
transmission), and/or from tick to tick via the host (horizontal transmission) depending on the pathogen. The co-feeding phenomenon allows some infectious agents, for instance the tick-borne encephalitis virus and bacteria responsible for Lyme disease, to be transmitted from an infected tick to an healthy tick at the site of the bite on an animal, in the absence of viremia or bacteremia in the host [17].

Although ticks may host various microorganisms (symbiotes and pathogens) that can be detected via their DNA, their presence in ticks is not necessarily associated with an infectious risk for humans. This is explained by several reasons: DNA detection may not necessarily mean that a living pathogen is present on the vector arthropod. And, even with a living infectious pathogen, the vector arthropod does not necessarily have the ability to transmit this pathogen [18]. For ticks infected with bacteria or parasites, the infectious agent is not immediately transmitted as bacteria and parasites have to mature and/or migrate towards salivary glands before being transmitted to the vertebrate hosts. This process may take 24 hours [19].

Ticks have been identified for thousands of year [20], and tick-associated pathogens have been observed for a long time as well, although most medical descriptions date from the $20^{\text {th }}$ century. One may, however, note that humans have had a major impact on the ecosystems of ticks. Forest culture - both deforestation and reforestation - has an impact on tick populations, just like changes in wildlife (disappearance of species, introduction of new species, proliferation of species attracting ticks, etc.) [21]. Climate change has an impact on ticks: they are now observed in northern regions of the world (Canada, Nordic countries) and at higher altitudes (above 1,500 meters), but they may also be less frequent in southern regions depending on their adaptive capacity. Better awareness of vector-borne diseases from health professionals and the general population, and improved direct diagnostic methods (mainly molecular biopsy, i.e. PCR, or culture) are associated with better management of patients and affected animals.

Although Ixodes ticks - prevalent in France - are likely to host various microorganisms, the risk of transmitting the infectious agent to humans following a tick bite is inferior to $3 \%$ according to a 
recent Dutch study [22]. Even when the infectious pathogen is transmitted to humans, all transmissions are not necessarily associated with clinical disease, as reported by a recent French study investigating the seroprevalence of seven pathogens (Borrelia burgdorferi sensu lato, Francisella tularensis, tick-borne encephalitis virus, Anaplasma phagocytophilum, Babesia spp., and Bartonella henselae) in forestry workers [23].

\subsection{Bacterial infections}

Borrelia spp. Bacteria of the Borrelia genus are spiral-shaped extracellular spirochetes belonging to Spirochaetales and to the Spirochaetaceae family. The Borrelia genus is divided into two groups: (1) Borrelia responsible for Lyme borreliosis, only transmitted by hard ticks of the Ixodes genus, and (2) Borrelia responsible for relapsing fever, mainly transmitted by soft ticks (Ornithodoros and Argas), except for body lice for B. recurrentis or hard ticks of the B. miyamotoi group [24]. Both of these groups have recently been reclassified as "Borreliella" and "Borrelia" genera, respectively, within the new Borreliaceae family [25]; however, for the sake of clarity, we use the former term "Borrelia" in the present article.

Lyme borreliosis. Bacteria responsible for Lyme disease belong to the B. burgdorferi sensu lato (sl) group, with 21 species identified. Lyme disease is the most prevalent vector-borne disease in the Northern Hemisphere. The vector is $I$. scapularis on the eastern coast of the United States and $I$. pacificus on the western coast. The main vectors in Europe are I. ricinus, and I. persulcatus in eastern Europe and Asia. The most pathogenic species for humans in Northern America is B. burgdorferi sensu stricto (ss), although other species of the complex are active in this region. In Europe, five species are observed in human pathologies: three are frequently observed ( $B$. burgdorferi ss, $B$. garinii, B. afzelii) and two are only rarely observed (B. spielmanii and B. bavariensis) [24]. The animal reservoir is highly varied, with rodents (B. afzelii and B. bavariensis) and birds (B. garinii and $B$. 
valaisiana) [26], due to specificities related to the host's immune system [27]. The immune system of incompetent hosts, such as deer, is able to kill Borrelia. However, these incompetent hosts contribute to maintaining large populations of ticks in the environment as they are the preferential hosts of adult ticks.

The most frequent clinical manifestation in humans is a typical cutaneous inflammation, i.e. erythema migrans (centrifugal inflammatory lesion of at least $5 \mathrm{~cm}$ ) (Figure 3). In the absence of antibiotic therapy, the lesion may progress to an early disseminated stage, and then to a late disseminated stage with cardiac, joint, neurological, or cutaneous involvement depending on the infectious agent [24].

The diagnosis is based on an ELISA assay. Any positive result should then be confirmed by Western blot [28]. The antibiotic therapy duration is two to four weeks, depending on molecules [29]. The likelihood of persisting clinical manifestations increases with diagnostic delays. However, one cannot talk about "chronic Lyme disease" because living bacteria can no longer be detected [30]. However, immunity against Lyme borreliosis is non-protective. A patient may thus be recurrently infected if frequently exposed to tick bites. The rate of Borrelia-infested ticks in France is usually around $10 \%$ to 20\%. Species mainly observed in ticks and humans are B. afzelii and B. garinii [31].

Tick-borne relapsing fever. Soft ticks such as Ornithodoros usually transmit these Borrelia species. More recently described in human pathology, B. miyamotoi is transmitted by hard ticks of the $I$. ricinus complex [32]. Although present in Europe, this species seems to be mainly pathogenic for immunodeficient people $[33,34]$.

A total of 22 species have been validated in this Borrelia group. They are observed in tropical areas (Africa mainly), but also in the United States [35]. The main symptoms of the infection are successive peaks of fever or "relapsing" fever due to changes in bacterial surface antigens. Such changes enable them to temporarily escape the host's immune system. Tick-borne relapsing fever is under-diagnosed in tropical regions because of the differential diagnosis of malaria. Diagnosis is based on May- 
Grünwald Giemsa staining of blood smears because, unlike Lyme borreliosis, bacteremia is high during a fever peak $\left(10^{5}-10^{7}\right.$ bacteria/ml).

Rickettsioses. Rickettsioses are transmitted by various arthropods, including ticks. The Rickettsia genus includes small intracellular Gram-negative bacteria. Rickettsia spp. associated with ticks are observed worldwide and the distribution area of each species is similar to that of its vector [36]. These bacteria interact with endothelial cells, thus increasing vascular permeability which is responsible for clinical manifestations [37]. A total of 25 pathogenic species have been identified, divided into three groups: typhus group (mainly transmitted by lice and fleas), spotted fever group, and a transitional group. Twenty of the 21 species of the spotted fever group are transmitted by ticks, acting both as the vector and main reservoir. Four main species are observed in France:

(1) R. conorii, responsible for Mediterranean spotted fever, is transmitted by Rhipicephalus sanguineus in the south of France, although also present in Europe, Asia, and Africa. After a one-week incubation period, acute fever onset is observed with headaches, arthralgia, and muscular pain. A black spot is observed at the bite site, followed by a rash after three to five days of fever (mainly on extremities). Severe cases have been reported with multiple organ dysfunction syndrome, mainly in Portugal [38];

(2) R. slovaca, R. raoultii (and R. rioja) are responsible for TIBOLA (tick-borne lymphadenopathy) or SENLAT (scalp eschar and neck lymphadenopathy) or DEBONEL (Dermacentor-borne necrosis erythema lymphadenopathy). They are transmitted by the Dermacentor tick. This is currently the most frequent rickettsiosis in Europe. After approximately a week of incubation (1 to 15 days), cervical adenopathy and black spots - most often on the scalp are observed; fever is not always present.

(3) R. helvetica, first described in 1993 in Switzerland and seemingly less pathogenic, is transmitted by Ixodes ricinus [38]. Pathogenicity varies by patient.

Treatment is based on doxycycline or azithromycin. 
Imported from Africa, R. africae is observed in France; it is transmitted by Amblyomma variegatum.

Human granulocytic anaplasmosis. The Anaplasmataceae family (Rickettsiales order) includes strictly intracellular bacteria of the Anaplasma and Ehrlichia genera, which are transmitted by ticks [39].

Human monocytotropic ehrlichiosis is caused by Ehrlichia chaffeensis. This species was first identified in humans in the 1990s and is only present in the United States. Its main reservoirs are white-tailed deer and its vector is the Amblyomma americanum tick.

Among species of the Anaplasma genus, A. phagocytophilum - responsible for human granulocytic anaplasmosis (HGA) - is the most important from a clinical standpoint [40]. A. phagocytophilum invades white cells (neutrophils, monocytes, and macrophages) and is usually found in vacuole as a morula. HGA has first been reported in 1994 on the eastern coast of the United States [41]. HGA is prevalent in temperate regions as it has been reported in both animals and humans in Europe, Asia, the United States, and Australia. Bacterial prevalence rates vary by country and by tick species, with rates between $<1 \%$ and $20 \%$ for $I$. ricinus in Western Europe and between $1.7 \%$ and $16.7 \%$ for I. persulcatus in Eastern Europe [42]. In France, 1-2\% of ticks are infected and human infections are mainly observed in Eastern France [31]. Differences in Anaplasma ecotypes could be responsible for prevalence disparities in humans. After one to three weeks of incubation following an infected tick bite, disease onset presents as fever and is frequently associated with chills, faintness, or generalized musculoskeletal pain with headaches and myalgia. Biological results usually show increased transaminase level, increased C-reactive protein level, and cytopenia (thrombopenia, neutropenia). The diagnosis of anaplasmosis is based on bacterial DNA detection on whole blood PCR. It can also be based on the detection of increased antibody levels after a four-week period. HGA treatment is based on doxycycline [43]. 
Candidatus Neoehrlichia mikurensis. This species has been described in Japan and belongs to the Anaplasmataceae family [44]. However, several reports such as in the Netherlands with I. ricinus ticks feeding on deer [45] as well as in Italy [44], had already highlighted the presence of gene sequences in this bacterium. The main reservoir is made of rodents and the vector is Ixodes spp., among which the prevalence is $1 \%-20 \%$ depending on European regions. Although a few human cases of infection have been reported, Candidatus Neoehrlichia mikurensis is mainly considered an emerging pathogen [46]. The bacterium invades endothelial cells. This pathogen is responsible for atypical symptoms, mainly in immunodeficient patients: fever, sepsis, and weight loss $[46,47]$. Infections caused by this bacterium are treated with doxycycline.

Ticks are also likely to transmit other bacteria, but their role as vectors is less important as there are other more effective transmission modes: e.g., for bacteria of the Coxiella, Bartonella, Francisella (etc.) genera.

Q fever. Coxiella burnetii is a Gram-negative, obligate, intracellular bacterium, commonly found in animal and human monocytes and macrophages. This bacterium is responsible for $Q$ fever, a worldwide zoonosis, and can infect numerous animal species [48]. Humans are contaminated through the respiratory route, when directly in contact with infected animals (mainly ruminants), or through the digestive route following consumption of dairy products or unpasteurized or poorly pasteurized derived dairy products. Ticks only play a secondary role in the transmission. Clinical manifestations of human $Q$ fever are influenza-like illness (fever, headaches, arthralgia, myalgia), atypical pneumonia, or hepatitis. Severity is related to the potential onset of a chronic infection (mainly endocarditis).

Tularemia. Francisella tularensis is a Gram-negative intracellular bacterium. Its prevalence is low, but it is highly virulent and contagious because of an easy dissemination and transmission via aerosols. $F$. 
tularensis is observed in various regions of the world, mainly in the Northern Hemisphere, and most often as sporadic cases [49]. It is mainly a zoonosis: the most receptive species are rodents and lagomorphs (hares). Dermacentor and Ixodes ticks can transmit tularemia. However, direct transmission is most frequent, with various transmission modes: direct contact with animals (scratches, bites, licks), ocular route, oral route (undercooked meat consumption), inhalation. The clinical presentation is highly varied and depends on the bacterial portal of entry. Disease onset is abrupt with an influenza-like illness. The ulceroglandular presentation is most frequent. Increased transmission of this bacterium by ticks has been reported in Switzerland in April 2018 by the Federal Office of Public Health [50].

Bartonellosis. Bacteria of the Bartonella genus are Gram-negative hemotrophic bacteria transmitted by arthropod vectors (sandflies - B. bacilliformis; body lice - B. quintana). A total of 13 species have been identified as potentially pathogenic for humans over the past 20 years: mainly $B$. henselae and B. quintana. Three species are commonly found on cats (B. henselae, B. clarridgeiae, B. koehlerae). However, ticks are believed to also transmit various Bartonella species, but the vector ability of $I$. ricinus has only been proven with $B$. henselae [51] and $B$. birtlesii [52]. Little human data is available to describe the role of ticks in Bartonella transmission.

\subsection{Viral infections}

Numerous viruses may be transmitted to humans and animals by ticks. Most of these viruses belong to three families of viruses transmitted by hard ticks: Bunyaviridae, Flaviviridae, and Reoviridae [53]. The most important tick-borne viral infection in humans are: tick-borne encephalitis virus (TBEV), endemic in Central and Eastern Europe; and Crimean-Congo hemorrhagic fever (CCHF) virus. 
Tick-borne encephalitis. The tick-borne encephalitis virus (TBEV) is an RNA virus belonging to the Flavivirus genus. Ticks acquire the virus during blood meals on a vertebrate host at the viremic phase, and then transmit it to their host during the following meal. Ticks may also acquire the virus when co-feeding on non-viremic or poorly viremic vertebrate hosts [17]. Vertical transmission (from female animals to newborn animals) has been reported in vector ticks, although not frequent $(<0.5 \%)[54]$. TBEV infection is the most important neuroinvasive disease transmitted by ticks in Europe and Asia, with thousands of human cases per year. Three virus subtypes have been reported, with geographical distributions more or less correlated with the vector geographical distributions: European subtype transmitted by I. ricinus and I. hexagonus ticks, and Siberian and Far Eastern subtypes both transmitted by I. persulcatus [55].

This virus is present as more or less stable microclusters, defined based on autochthonous human cases and/or on its detection among field-collected ticks. Other animals may act as competent reservoirs: wild animals such as micromammals (field mice, voles), foxes, wild boars, deer [56], but also domestic animals (goats, cows, sheep, and dogs) [57]. TBEV prevalence rates among I. ricinus ticks in Europe usually vary from $0.1 \%$ to $1.22 \%$ depending on countries, studied areas, and analyzed tick stages [58].

The human infection is seasonal, with a peak during spring and summer due to the activity of vector ticks. Another contamination mode has been reported, through the ingestion of raw dairy products (cheese, milk) from infected domestic animals [56].

The infection may be asymptomatic. Following incubation, the typical manifestation presents as an influenza-like illness. Following temporary improvement for a few days, meningitis symptoms may be inconsistently observed and may be associated with encephalitis signs in $50 \%$ of patients and with myelitis signs in less than $10 \%$ of patients. The case fatality is $0.5 \%-3 \%$ for the European and Siberian subtypes, but reaches $35 \%$ for the Far Eastern subtype [56]. An effective vaccine is available for this infection. A sharp increase in tick-borne encephalitis cases was reported in 2016 in Eastern France [59]. 
Crimean-Congo hemorrhagic fever. The disease was first characterized in the 1940s in the Crimea when a severe hemorrhagic fever epidemic sparked. The virus was then coined "Crimean-Congo hemorrhagic fever virus" (CCHFV), following isolation of the antigenically identical Congo virus in 1956. The virus belongs to the Nairovirus genus from the Bunyaviridae family. It is a large, enveloped, double-stranded DNA virus (group I).

CCHFV distribution reflects the geographical distribution of vector tick species, mainly those of the Hyalomma genus but also of the Dermacentor and Rhipicephalus genera. The virus is observed in Africa, Europe, and Western Asia, but it has never been reported in the New World. Little data is available on the virus prevalence among ticks, and results vary $(0.7 \%$ to $33 \%)$ depending on the detection technique and on the tested tick species. The virus circulates via an enzootic cycle including a large panel of vertebrate hosts among which the virus is asymptomatic; only humans contract the disease. The main vertebrate hosts of the virus are hares, hedgehogs, rodents, and domestic species (bovine animals, sheep, caprines, horses, and pigs). Domestic hosts are considered viral enhancers: they are viremic for at least one week following contamination and develop specific antibodies targeting the virus that can be detected by serological testing.

Tick bite remains the main infectious route in humans. However, contacts with infected bodily fluids or tissues from viremic animals may lead to contaminations [60]. CCHF human infection is characterized by epidemic flares in summer, enabling cluster identification. This is an emerging infection. The clinical presentation is characterized by fever that may lead to a fatal hemorrhagic syndrome in 50\% of cases. Two cases of CCHF were reported in 2016 in Spain following tick bites, including one death [54]. The prevalence of the virus among ticks is relatively low in Europe (Turkey is particularly affected though). The presence of $H$. marginatum vector has been confirmed in Camargue and in the area of Montpellier, France [54]. Migratory birds from Africa also play a role in the virus circulation [61]. 


\subsection{Parasitic infections}

Babesiosis or piroplasmosis. Ticks may transmit parasites (helminths and Apicomplexa protists); members of the Babesia genus are the most pathogenic for humans. Babesia sp. is highly similar to Plasmodium sp. (responsible for malaria), but sporozoites of Babesia sp. are present in the salivary glands of ticks and directly penetrate into red blood cells (no hepatic cycle).

More than 100 species have been characterized and classified as small or large Babesia spp. The most pathogenic species for humans are $B$. microti and $B$. divergens, and more recently $B$. venatorum (Babesia sp. EU1). Ixodes ticks are the vectors of these species. Transmission of the parasite at the sporozoite stage occurs only a few days after attaching to the host as they first need to mature inside salivary glands. Natural hosts of these species, acting as reservoirs, are rodents, bovine animals, and deer [62].

Human babesiosis cases are rare but severe; they are mainly observed in immunodeficient individuals $(40 \%$ case fatality). Two $B$. divergens infection cases have been reported in immunocompetent patients in 2009 in Eastern France [63]. Humans and animals may also be contaminated via blood transfusions [40]. The clinical presentation depends on the host's immune status and on the involved Babesia species. The main symptoms of human babesiosis are fever, jaundice, anemia, and hemoglobinuria. Treatment in humans depends on the patient's immune system: combination of atovaquone and azithromycin in immunocompetent patients, and clindamycin and quinine for severe cases [62].

\section{Prevention}

\subsection{Individual-based prevention}

Physical prevention. Larva and nymph bites from Ixodes ticks are the most difficult to detect because of their small size (Figure 4). Primary prevention against ticks is mainly based on simple measures 
such as wearing long and bright clothes (Figure 5), tucking one's trousers inside socks, wearing a cap for children to avoid bites on the scalp - although it should be noted that ticks do not fall from trees. People should also check their body for ticks after being outdoors in infested areas: any warm and humid body parts, skin folds, belly button, genitals, ears, and scalp.

Skin repellents. Primary prevention against ticks may also rely on the use of skin repellents [64]. Data update is currently underway on the effectiveness of skin repellents against tick bites $[65,66]$. Specificities for the use of these skin repellents are updated every year in the monthly epidemiological report (French acronym BEH) published by the French national agency for public health (Santé publique France) [67].

Repellents do not kill ticks; they only repel them, preventing them from biting humans or animals. The choice of repellent depends on various factors, including the individual's status (age, pregnant woman), and on the intention for use. For all repellents, attention should be paid to the nature and proportion of active ingredients, to the duration of action, and to the maximum daily applications. The pharmaceutical form also plays an important role in the repellent activity.

Current repellents are based on external application molecules (on skin or clothes). Four molecules are known to be effective against tick bites:

(1) PMD (P-menthane-3, 8-diol), Corymbia citriodora eucalyptus extract;

(2) DEET (diethyltoluamide) has been largely used for several decades and is the reference molecule. However, it is known to impair synthetic fibers (rayon, spandex, vinyl, etc.) and plastic materials (glasses, watch strap);

(3) IR35/35® (N-butyl, N-acetyl-3-ethylaminopropionate);

(4) KBR 3023 or picaridin (piperidine-1-carboxylic acid). 
Other natural products are being studied, such as 2-undecanone (BioUD ${ }^{\circledR}$ ) derived from tomatoes, decanoic acid (Contrazek ${ }^{\circledR}$ ) derived from coconut or palm kernel, geraniol, Margosa extract or margosa (Neem), and lavender extract. The other essential oils are usually not recommended or very rarely recommended as they are highly volatile. Their repellent effect is limited to 20 minutes to one hour. Some components of these essential oils are skin irritants (citral, farnesol, trans-2-hexenal) or carcinogenic (eugenol) [68].

Repellent-treated clothing. Repellent-treated clothing is an alternative to skin repellents. Permethrin is widely used. It may be applied as a spray (on the external side of clothes in a ventilated area, and must be left to dry), with a 6-week effectiveness. Cloth immersion in a permethrin bath is more effective. The repellent effect lasts six months and resists to several washings.

Other individual-based protection measures. Following a tick bite, mechanical extraction of the tick is the best effective method and must be performed as rapidly as possible to avoid any potential transmission of pathogens [64]. Tick removers are particularly useful and should be recommended (Figure 5). However, using products such as oil, ether, or nail polish to facilitate the tick removal is useless. No study has demonstrated the effectiveness of such products.

\subsection{Collective measures}

Environmental treatment of at-risk housing areas may be performed, and mainly consists of getting rid of falling leaves and of mowing lawns. Green areas are more and more frequent in urban areas, and may represent targeted ecosystems [11]. Building up fences around housing areas helps keep deer at bay, as they are the main carriers of adult ticks [69].

\section{Conclusion and perspectives}


Vector-borne diseases transmitted by ticks have been on the rise worldwide since the start of the $20^{\text {th }}$ century because of increased human activities with an impact on forest ecosystems, wild life animals, and domestic animals. In the Northern Hemisphere, human diseases such as Lyme borreliosis are the most prevalent. However, in southern countries vector-borne veterinary diseases have an impact on socio-economic issues, due to invasive ticks which are disease vectors for livestock. Most of these tick-borne diseases are zoonotic diseases, and the interaction between hosts-vectors-pathogens is still poorly understood for most of them. Tick and tick-borne disease research has been neglected compared with mosquito-borne diseases (malaria, dengue, Zika, etc.). It must be developed to further knowledge on tick circulation and persistence in the environment, infectious agent transmission and persistence among vectors and vertebrate hosts to develop effective multidisciplinary control measures (tick control, diagnosis, vaccine). 


\section{References}

[1] Guglielmone A, Richad R, Apanaskevich D, Petney T, Estrada-Pena A, Horak IG, et al. The Argasidae, Ixodidae and Nuttalliellidae (Acari: Ixodida) of the world: a list of valid species names. Zootaxa 2010;2528:1-28.

[2] Apanaskevich D, Oliver JJ. Life cycles and natural history of ticks. In: Sonenshine D, Roe RM, editors. Biol. ticks. second edi, Oxford University Press; 2014, p. 59-73.

[3] Bonnet S, Boulanger N. Ixodes Tick Saliva: A potent controller at the skin Interface of early Borrelia burgdorferi sensu lato transmission. In: Wikel S, Aksoy S, Dimopoulos G, editors. Arthropod Vector Controll. Dis. Transm. Vol., LONDON (GBR) : ACADEMIC PRESS LTD-ELSEVIER SCIENCE LTD; 2017, p. 231-48.

[4] Hall-Mendelin S, Craig S, Hall R, O'Donoghue P, Atwell R, Tulsiani S, et al. Tick paralysis in Australia caused by Ixodes holocyclus Neumann. Ann Trop Med Parasitol 2011;105:95-106.

[5] Wilhelmsson P, Lindblom P, Fryland L, Nyman D, Jaenson T, Forsberg P, et al. Ixodes ricinus ticks removed from humans in Northern Europe: seasonal pattern of infestation, attachment sites and duration of feeding. Parasit Vectors 2013;6:362.

[6] Hilger C, Bessot JC, Hutt N, Grigioni F, De Blay F, Pauli G, et al. IgE-mediated anaphylaxis caused by bites of the pigeon tick Argas reflexus: cloning and expression of the major allergen Arg r 1. J Allergy Clin Immunol 2005;115:617-22. doi:10.1016/j.jaci.2004.11.052.

[7] Commins SP, Platts-Mills T a E. Tick bites and red meat allergy. Curr Opin Allergy Clin Immunol 2013;13:354-9. doi:10.1097/ACl.0b013e3283624560.

[8] Gilot B, Marjolet M. Contribution à l'étude du parasitisme humain par les tiques (Ixodidae et Argasidae), plus particulièrement dans le sud-est de la France. Med Mal Infect 1982;12:34051.

[9] Perez-Eid C. Les tiques: identification, biologie, importance médicale et vétérinaire. Editions T. 
Lavoisier; 2007.

[10] Ministère de la santé: Plan Lyme 2016.https://solidarites-

sante.gouv.fr/IMG/pdf/plan_lyme_180117.pdf. n.d., accessed on June 2018

[11] Gassner F, Hansford K, Medlock J. Greener cities, a wild card for ticks ? In: Braks MAH, Van Wieren SE, Takken W SH, editor. Ecol. Prev. Lyme borreliosis. Ecology an, Wageningen Academic Publishers; 2016, p. 187-203.

[12] Medlock JM, Hansford KM, Bormane A, Derdakova M, Estrada-Peña A, George J-C, et al. Driving forces for changes in geographical distribution of Ixodes ricinus ticks in Europe. Parasit Vectors 2013;6:1. doi:10.1186/1756-3305-6-1.

[13] Humair P, Gern L. The wild hidden face of Lyme borreliosis in Europe. Microbes Infect $2000 ; 2: 915-22$.

[14] Bonnet S, Huber K, Joncour G, René-Martellet M, Stachurski F, Zenner L. La biologie des tiques. In: McCoy K, Boulanger N, editors. Tiques Mal. à tiques Biol. écologie évolutive épidémiologie., IRD édition, Marseille.; 2016.

[15] Dantas-Torres F, Chomel BB, Otranto D. Ticks and tick-borne diseases: a One Health perspective. Trends Parasitol 2012;28:437-46. doi:10.1016/j.pt.2012.07.003.

[16] Piesman J, Eisen L. Prevention of tick-borne diseases. Annu Rev Entomol 2008;53323-43 2008;53:323-43.

[17] Randolph S, Gern L, Nuttall P. Co-feeding ticks: Epidemiological significance for tick-borne pathogen transmission. Parasitol Today 1996 Dec;12(12)472-9 1996;12:472-9.

[18] Kahl O, Gern L, Eisen L, Lane RS. Ecological research on Borrelia burgdorferi sensu lato: terminology and some methodological pitfalls. Lyme borreliosis Biol. Epidemiol. Control., CABI; First edition; 2002, p. 29-46.

[19] de la Fuente J, Contreras M, Estrada-Peña A, Cabezas-Cruz A. Targeting a global health 
problem: Vaccine design and challenges for the control of tick-borne diseases. Vaccine 2017;17:S0264-410X(17)31023-X.

[20] Peñalver E, Arillo A, Delclòs X, Peris D, Grimaldi D, Anderson, SR, Nascimbene, PC, Perez-de la Fuente R. Ticks parasitised feathered dinosaurs as revealed by Cretaceous amber assemblages. Nat Commun 2017;8:1924-37.

[21] Kilpatrick A, Randolph S. Drivers, dynamics, and control of emerging vector-borne zoonotic diseases. Lancet 2012;380:1946-55.

[22] Jahfari S, Hofhuis A, Fonville M, van der Giessen J, van Pelt W, Sprong H. Molecular Detection of Tick-Borne Pathogens in Humans with Tick Bites and Erythema Migrans, in the Netherlands. PLoS NegI Trop Dis 2016;10:e0005042. doi:10.1371/journal.pntd.0005042.

[23] Rigaud E, Jaulhac B, Garcia-Bonnet N, Hunfeld KP, Féménia F, Huet D, et al. Seroprevalence of seven pathogens transmitted by the Ixodes ricinus tick in forestry workers in France. Clin Microbiol Infect 2016:1-9. doi:10.1016/j.cmi.2016.05.014.

[24] Stanek G, Wormser G, Gray J, Strle F. Lyme borreliosis. Lancet 2012;379:461-73. doi:10.1016/S0140-6736(11)60103-7.

[25] Adeolu M, Gupta RS. A phylogenomic and molecular marker based proposal for the division of the genus Borrelia into two genera: the emended genus Borrelia containing only the members of the relapsing fever Borrelia, and the genus Borreliella gen. nov. containing the members 0. Antonie Van Leeuwenhoek 2014;105:1049-72. doi:10.1007/s10482-014-0164-x.

[26] Gern L. Life cycle of Borrelia burgdorferi sensu lato and transmission to humans. Curr Probl Dermatol 2009;37.

[27] Kurtenbach K, Hanincová K, Tsao JI, Margos G, Fish D, Ogden NH. Fundamental processes in the evolutionary ecology of Lyme borreliosis. Nat Rev Microbiol 2006;4:660-9. doi:10.1038/nrmicro1475. 
[28] Stanek G, Fingerle V, Hunfeld K, Jaulhac B, Kaiser R, Krause A, et al. Lyme borreliosis: clinical case definitions for diagnosis and management in Europe. Clin Microbiol Infect 2011;17:6979.

[29] Borchers A, Keen C, Huntley A, Gershwin M. Lyme disease: a rigorous review of diagnostic criteria and treatment. J Autoimmun 2015;57:82-115.

[30] Sordet C. Chronic Lyme disease: fact or fiction? Jt Bone Spine 2014;81:110-1.

[31] Boulanger N, Zilliox L, Goldstein V, Boyer P, Napolitano D, Jaulhac B. Surveillance du vecteur de la borréliose de Lyme, Ixodes ricinus, en Alsace de 2013 à 2016. Bull Epidemiol Hebd 2018;19-20:400-5.

[32] Platonov A, Karan L, Kolyasnikova N, Makhneva N, Toporkova M, Maleev V, et al. Humans infected with relapsing fever spirochete Borrelia miyamotoi, Russia. Emerg Infect Dis 2011;17:1816-23.

[33] Hovius JWR, De Wever B, Sohne M, Brouwer MC, Coumou J, Wagemakers A, et al. A case of meningoencephalitis by the relapsing fever spirochaete Borrelia miyamotoi in Europe. Lancet 2013;382:658.

[34] Boden K, Lobenstein S, Hermann B, Margos G, Fingerle V. Borrelia miyamotoi - Associated neuroborreliosis in immunocompromised person. Emerg Infect Dis 2016;22:1617-20.

[35] Talagrand-Reboul E, Boyer P, Bergström S, Vial L, Boulanger N. Relapsing Fevers: Neglected Tick-Borne Diseases. Front Cell Infect Microbiol 2018;8:98.

[36] Parola P, Paddock, CD, Socolovschi C, Labruna M, Mediannikov O, Kernif T, Abdad M, et al. Update on tick-borne rickettsioses around the world: a geographic approach. Clin Microbiol Rev 2013;26:657-702.

[37] Blanton L. Rickettsial infections in the tropics and in the traveler. Curr Opin Infect Dis 2013;26:435-40. 
[38] Oteo J, Portillo A. Oteo JA, Portillo A. Tick-borne rickettsioses in Europe. Ticks Tick Borne Dis $2012 ; 3: 271-8$.

[39] Dumler J, Barbet A, Bekker C, Dasch G, Palmer G, Ray S, et al. Reorganization of genera in the families Rickettsiaceae and Anaplasmataceae in the order Rickettsiales: unification of some species of Ehrlichia with Anaplasma, Cowdria with Ehrlichia and Ehrlichia with Neorickettsia, descriptions of six new species combi. Int J Syst Evol Microbiol 2001;51:2145-65.

[40] Koenen F, Pascucci I, Jaenson T, Madder M, de Sousa R, Estrada-Pena A, et al. Tick borne infections (including zoonoses) in Europe and the Mediterranean Basin. Tick Tick Borne Dis Chap 4, 2013:33-76.

[41] Woldehiwet Z. The natural history of Anaplasma phagocytophilum. Vet Parasitol 2010;167:108-22. doi:10.1016/j.vetpar.2009.09.013.

[42] Stuen S, Granquist E, Silaghi C. Anaplasma phagocytophilum--a widespread multi-host pathogen with highly adaptive strategies. Front Cell Infect Microbiol 2013;3:31.

[43] Koebel C, Kern A, Edouard S, Hoang A, Celestin N, Hansmann Y, et al. Human granulocytic anaplasmosis in eastern France: clinical presentation and laboratory diagnosis. Diagn Microbiol Infect Dis 2012;72:214-8.

[44] Kawahara M, Rikihisa $Y$, Isogai E, Takahashi M, Misumi H, Suto C, et al. Ultrastructure and phylogenetic analysis of "Candidatus Neoehrlichia mikurensis" in the family Anaplasmataceae, isolated from wild rats and found in Ixodes ovatus ticks. Int J Syst Evol Microbiol 2004;54:1837-43.

[45] Schouls L, Van De Pol I, Rijpkema S, Schot C. Detection and identification of Ehrlichia, Borrelia burgdorferi sensu lato, and Bartonella species in Dutch Ixodes ricinus ticks. J Clin Microbiol 1999;37:2215-22.

[46] Silaghi C, Beck R, Oteo J, Pfeffer M, Sprong H. Neoehrlichiosis: an emerging tick-borne zoonosis caused by Candidatus Neoehrlichia mikurensis. Exp Appl Acarol 2016;68:279-97. 
[47] Grankvist A, Andersson P, Mattsson M, Sender M, Vaht K, Höper L, et al. Infections with the tick-borne bacterium "Candidatus Neoehrlichia mikurensis" mimic noninfectious conditions in patients with B cell malignancies or autoimmune diseases. Clin Infect Dis. 2014 Jun;58(12):1716-22. Clin Infect Dis 2014;58:1716-22.

[48] Roest H, Bossers A, Van Zijderveld F, Rebel J. Clinical microbiology of Coxiella burnetii and relevant aspects for the diagnosis and control of the zoonotic disease $Q$ fever. Vet $Q$ 2013;33:148-6.

[49] Steiner D, Furuya Y, Metzger D. Host-pathogen interactions and immune evasion strategies in Francisella tularensis pathogenicity. Infect Drug Resist 2014 Sep 18;7239-51 2014;7:239-51.

[50] Office fédéral de Santé Suisse: Tularémie en Suisse.

https://www.bag.admin.ch/bag/fr/home/krankheiten/krankheiten-imueberblick/tularaemie.html. Accessed on June 2018. n.d.

[51] Cotte V, Bonnet S, Le Rhun D, Le Naour E, Chauvin A, Boulouis HJ, et al. Transmission of Bartonella henselae by Ixodes ricinus . Emerg Infect Dis 2008;14:1074-80. doi:10.3201/eid1407.071110.

[52] Reis C, Cote M, Le Rhun D, Lecuelle B, Levin ML, Vayssier-Taussat M, et al. Vector competence of the tick Ixodes ricinus for transmission of Bartonella birtlesii . PLoS Negl Trop Dis 2011;5:e1186. doi:10.1371/journal.pntd.0001186.

[53] Lani R, Moghaddam E, Haghani A, Chang LY, AbuBakar S, Zandi K. Tick-borne viruses: A review from the perspective of therapeutic approaches. Ticks Tick Borne Dis 2014;5:457-65. doi:10.1016/j.ttbdis.2014.04.001.

[54] Lindquist L, Vapalahti O. Tick-borne encephalitis. Lancet 2008;371:1861-71.

[55] Süss J. Tick-borne encephalitis 2010: epidemiology, risk areas, and virus strains in Europe and Asia-an overview. Ticks Tick Borne Dis 2011;2:2-15. 
[56] Mansfield KL, Johnson N, Phipps LP, Stephenson JR, Fooks a R, Solomon T. Tick-borne encephalitis virus - a review of an emerging zoonosis. J Gen Virol 2009;90:1781-94. doi:10.1099/vir.0.011437-0.

[57] eCDC: Tick-borne encephalitis in Europe. https://ecdc.europa.eu/sites/portal/files/documents/AER_for_2016-TBE.pdf. Accessed on June 2018. n.d.

[58] Lommano E, Burri C, Maeder G, Guerne M, Bastic V, Patalas E, et al. Prevalence and genotyping of tick-borne encephalitis virus in questing Ixodes ricinus ticks in a new endemic area in western Switzerland. J Med Entomol 2012;49:156-64.

[59] Velay A, Solis M, Kack-Kack W, Gantner P, Maquart M, Martinot M, et al. A new hot spot for tick-borne encephalitis (TBE): A marked increase of TBE cases in France in 2016. Ticks Tick Borne Dis. 2018 Jan;9(1):120-125. Ticks Tick Borne Dis 2018;9:120-5.

[60] Mertens M, Schmidt K, Ozkul A GM. The impact of Crimean-Congo hemorrhagic fever virus on public health. Antivir Res 2013;98:248-60.

[61] Plateforme ESA: Epidémiosurveillance en Santé Animale: Fièvre Criéé-Congo septembre 2016. https://www.plateforme-esa.fr/article/declaration-de-deux-cas-humains-de-fievrehemorragique-de-crimee-congo-en-espagne. Accessed on June 2018. n.d.

[62] Vannier E, Krause P. Human babesiosis. N Engl J Med 2012;366:2397-407.

[63] Martinot M, Zadeh MM, Hansmann Y, Grawey I, Christmann D, Aguillon S, et al. Babesiosis in immunocompetent patients, Europe . Emerg Infect Dis 2011;17:114-6. doi:10.3201/eid1701.100737.

[64] Pages F, Dautel H, Duvallet G, Kahl O, de Gentile L, Boulanger N. Tick repellents for human use: prevention of tick bites and tick-borne diseases. Vector Borne Zoonotic Dis 2014;14:8593. doi:10.1089/vbz.2013.1410. 
[65] ANSES: répulsifs et tiques. https://www.anses.fr/fr/system/files/BIOC2018SA0105.pdf. Accessed on June 2018. n.d.

[66] Krober T, Bourquin M, Guerin P. A standardised in vivo and in vitro test method for evaluating tick repellents. Pestic Biochem Physiol 2013;107:160-8.

[67] Conseils aux voyageurs, BEH 2018.

https://www.anses.fr/fr/system/files/BIOC2018SA0105.pdf. Accessed on June 2018. n.d.

[68] Strickman D, Frances S, Debboun M. Prevention of bug bites, stings and disease. 2009:321.

[69] Kilpatrick HJ, LaBonte AM, Stafford KC. The relationship between deer density, tick abundance, and human cases of Lyme disease in a residential community. J Med Entomol 2014;51:777-84. 
Figure 1. Various genera of ticks. From left to right: dorsal side of ticks with Ixodes ricinus, Dermacentor, and Rhipicephalus hard ticks and Argas reflexus soft tick. For I. ricinus, feeding structures are particularly large and for Argas reflexus, they cannot be seen as they are located on the stomach.

(Photo credit: JM Bérenger - Vitrome, IHU Méditerranée Infection - Marseille)

Figure 1. Différents genres de tiques. De gauche à droite: tiques en face dorsale avec tiques dures Ixodes ricinus, Dermacentor et Rhipicephalus, tique molle Argas reflexus. Note pour I. ricinus, les pièces piqueuses particulièrement grandes et pour Argas reflexus les pièces piqueuses non visibles car présentes sur la face ventrale.

(Crédit photo : JM Bérenger - Vitrome, IHU Méditerranée Infection - Marseille)
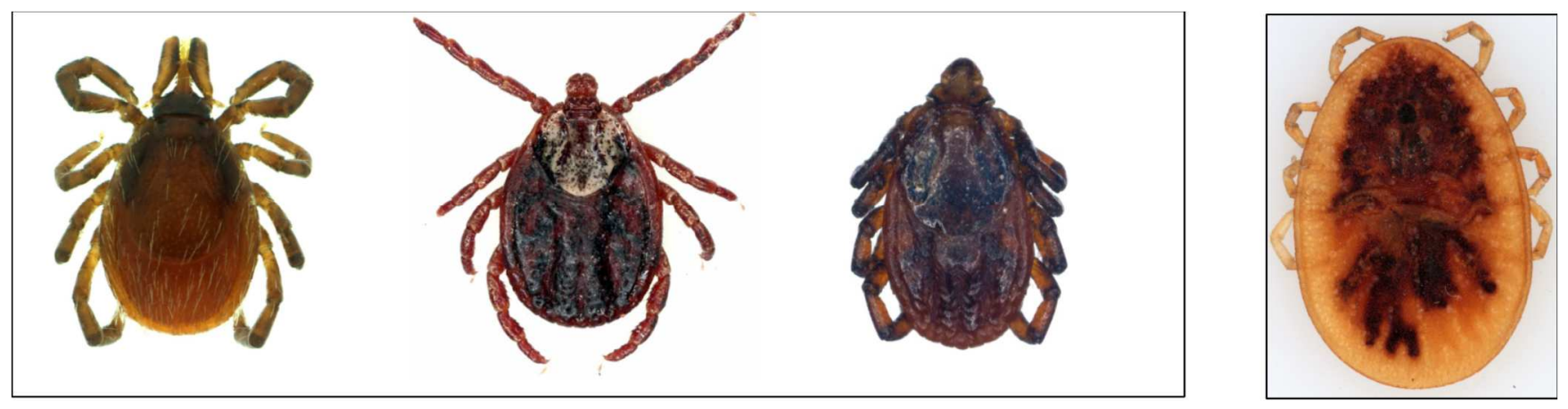
Figure 2. Questing ticks: A. Dermacentor reticulatus female tick, B. Ixodes ricinus female tick (Photo credit: N. Boulanger)

Figure 2. Tiques à l'affût. A. Femelle de Dermacentor reticulatus. B. Femelle d'Ixodes ricinus. (Crédit photo : N. Boulanger)
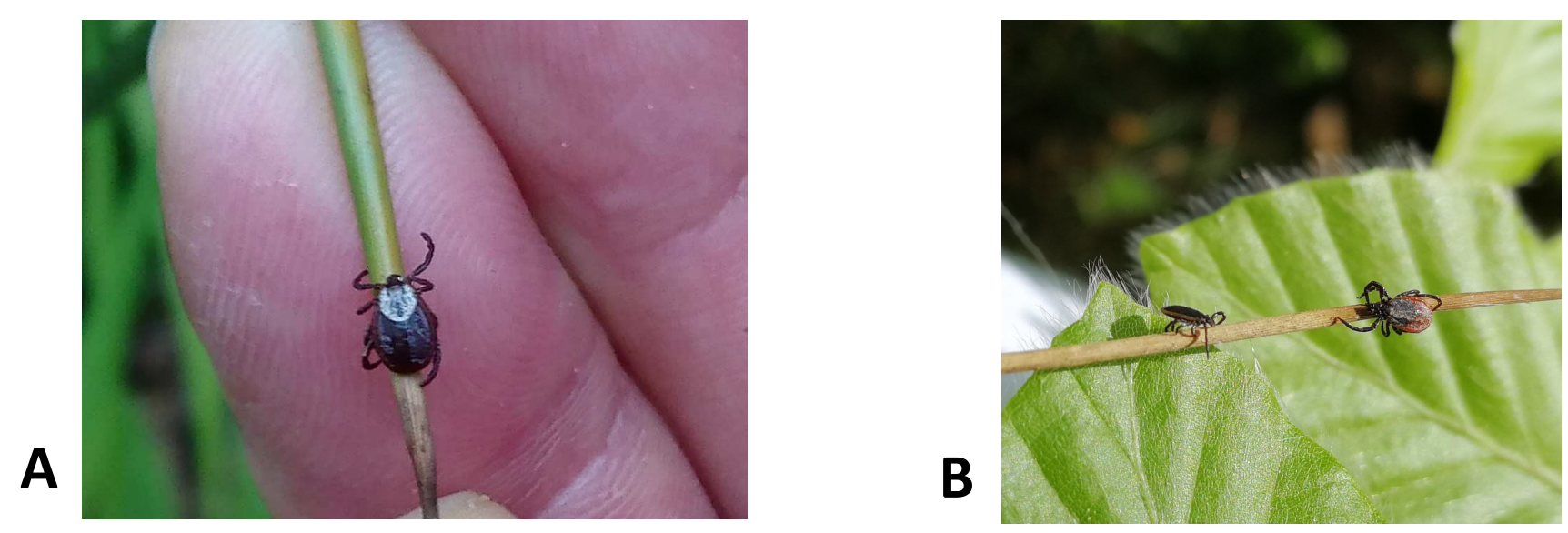
Figure 3. Erythema migrans associated with Lyme borreliosis, (A) Typical presentation, (B) Atypical presentation. (C) Inflammatory reaction to the tick bite, probably associated with saliva. (Photo credit: C. Lenormand, Clinique Dermatologique, Strasbourg, and N. Boulanger).

Figure 3. Érythème migrant lors d'une borréliose de Lyme, (A) Typique, (B) Non typique (C) Réaction inflammatoire à la piqûre de tique, probablement associée à la salive. (Crédit photo : C. Lenormand, Clinique Dermatologique, Strasbourg et N. Boulanger).

A

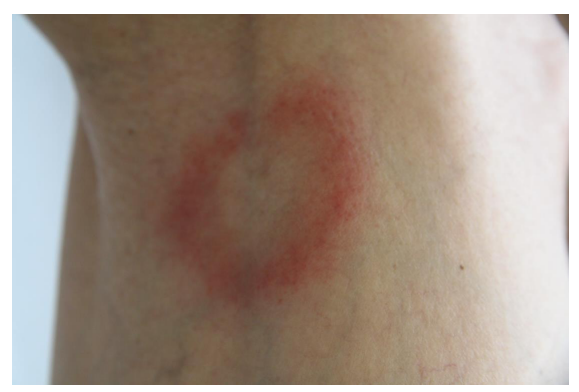

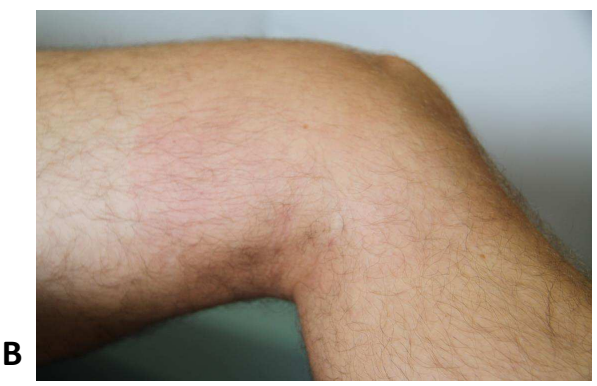

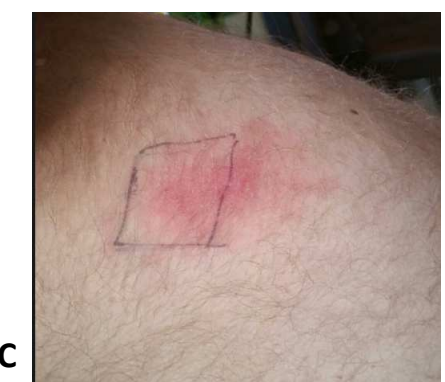


Figure 4. Tick bites from Ixodes ricinus (A) Larva and (B) Nymph. (Photo credit: N. Boulanger)

Figure 4. Piqûre de tique Ixodes ricinus (A) Larve et (B) Nymphe. (Crédit photo : N. Boulanger)
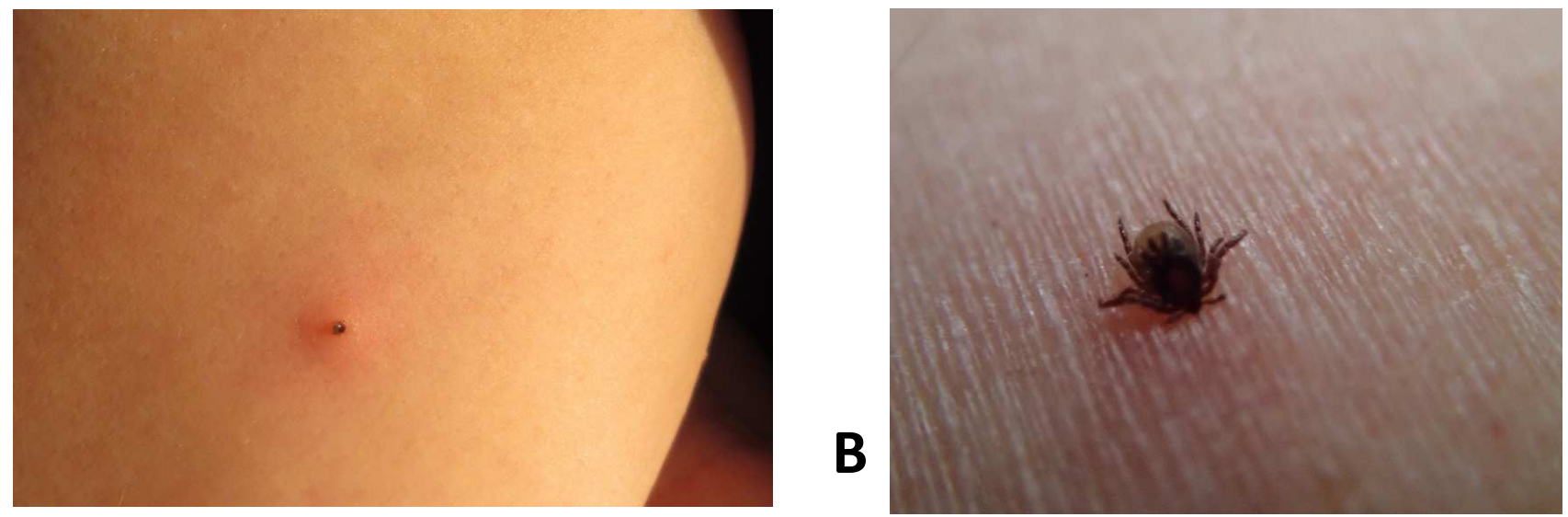
Figure 5. Bright clothes are an excellent individual-based primary prevention measure as adult ticks (A) or nymph (B) of Ixodes ricinus can be easily spotted. Tick removers are highly effective for removing ticks (C). (Photo credit: N. Boulanger)

Figure 5. Les vêtements clairs constituent un excellent moyen de prévention primaire individuelle car ils permettent de repérer facilement une tique adulte (A) ou une nymphe (B) d'Ixodes ricinus. Le tiretique est très efficace pour l'extraction des tiques (C). (Crédit photo : N. Boulanger)
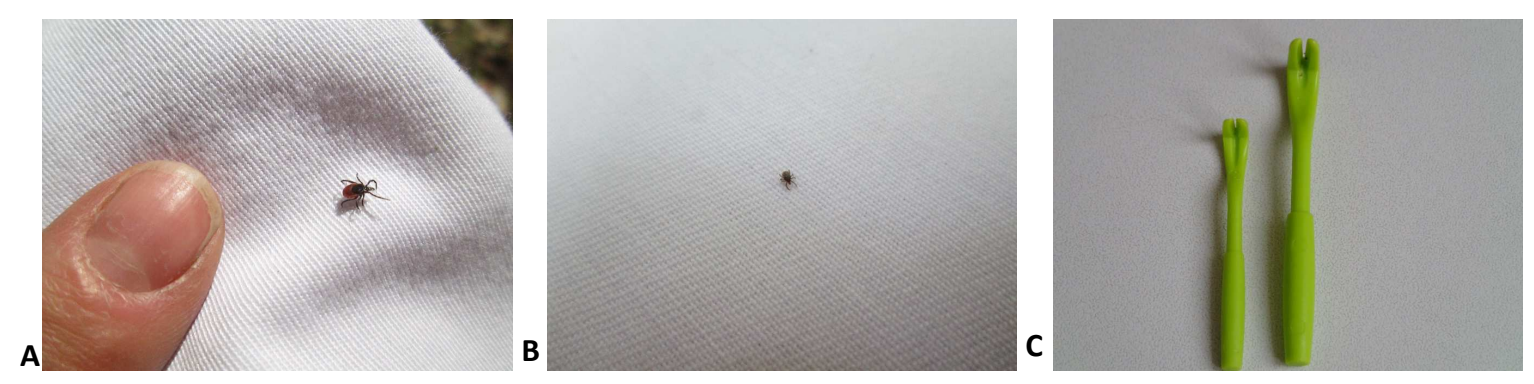
Table 1. Main human infectious diseases transmitted by ticks

Tableau 1. Principales pathologies infectieuses humaines transmises par les tiques

\begin{tabular}{|c|c|c|c|c|}
\hline Diseases & Infectious agents & Vector ticks & $\begin{array}{l}\text { Hosts acting as } \\
\text { reservoirs }\end{array}$ & $\begin{array}{l}\text { Geographical } \\
\text { distribution }\end{array}$ \\
\hline \multicolumn{5}{|c|}{ Virus (arbovirus) } \\
\hline $\begin{array}{l}\text { Tick-borne } \\
\text { encephalitis }\end{array}$ & Flavivirus & $\begin{array}{l}\text { Ixodes ricinus } \\
\text { I. persulcatus }\end{array}$ & $\begin{array}{l}\text { Wild mammals, } \\
\text { vectors }\end{array}$ & Asia, Europe \\
\hline $\begin{array}{l}\text { Crimean-Congo } \\
\text { hemorrhagic fever }\end{array}$ & Nairovirus & $\begin{array}{l}\text { Hyalomma } \\
\text { marginatum }\end{array}$ & $\begin{array}{l}\text { Wild mammals, } \\
\text { vectors }\end{array}$ & $\begin{array}{l}\text { Europe, Asia, } \\
\text { Africa }\end{array}$ \\
\hline \multicolumn{5}{|c|}{ Bacteria } \\
\hline Q fever or coxiellosis & Coxiella burnetii & $\begin{array}{l}\text { Rhipicephalus } \\
\text { spp. } \\
\text { Dermacentor } \\
\text { spp. }\end{array}$ & Mammals & Worldwide \\
\hline Lyme borreliosis & $\begin{array}{l}\text { Borrelia } \\
\text { burgdorferi sensu } \\
\text { lato }\end{array}$ & Ixodes spp. & $\begin{array}{l}\text { Small mammals, } \\
\text { birds, reptiles }\end{array}$ & $\begin{array}{l}\text { Northern } \\
\text { Hemisphere }\end{array}$ \\
\hline $\begin{array}{l}\text { Borrelioses/tick- } \\
\text { borne recurrent } \\
\text { fever }\end{array}$ & Borrelia spp. & $\begin{array}{l}\text { Ornithodoros } \\
\text { spp. } \\
\text { Ixodes spp. }\end{array}$ & Rodents & $\begin{array}{l}\text { Europe, Northern } \\
\text { America, tropical } \\
\text { and subtropical } \\
\text { regions }\end{array}$ \\
\hline $\begin{array}{l}\text { Mediterranean } \\
\text { spotted fever }\end{array}$ & Rickettsia conorii & $\begin{array}{l}\text { Rhipicephalus } \\
\text { sanguineus }\end{array}$ & Dogs & $\begin{array}{l}\text { Africa, Asia, } \\
\text { Europe }\end{array}$ \\
\hline $\begin{array}{l}\text { Tick-borne African } \\
\text { fever }\end{array}$ & Rickettsia africae & $\begin{array}{l}\text { Amblyomma } \\
\text { spp. }\end{array}$ & Mammals & $\begin{array}{l}\text { Sub-Saharan } \\
\text { Africa }\end{array}$ \\
\hline $\begin{array}{l}\text { TIBOLA (tick-borne } \\
\text { lymphadenopathy) }\end{array}$ & $\begin{array}{l}\text { Rickettsia } \\
\text { slovaca, } \\
\text { R. raoultii, R. rioja }\end{array}$ & $\begin{array}{l}\text { Dermacentor } \\
\text { spp. }\end{array}$ & Sheep, deer & Europe \\
\hline Tularemia & $\begin{array}{l}\text { Francisella } \\
\text { tularensis }\end{array}$ & $\begin{array}{l}\text { Various } \\
\text { genera of ticks }\end{array}$ & $\begin{array}{l}\text { Jackrabbits, } \\
\text { rabbits, rodents }\end{array}$ & Worldwide \\
\hline
\end{tabular}




\begin{tabular}{|l|l|l|l|l|}
\hline \multicolumn{1}{|c|}{ Diseases } & Infectious agents & Vector ticks & \multicolumn{1}{|c|}{$\begin{array}{c}\text { Hosts acting as } \\
\text { reservoirs }\end{array}$} & $\begin{array}{l}\text { Geographical } \\
\text { distribution }\end{array}$ \\
\hline $\begin{array}{l}\text { Human granulocytic } \\
\text { anaplasmosis }\end{array}$ & $\begin{array}{l}\text { Anaplasma } \\
\text { phagocytophilum }\end{array}$ & $\begin{array}{l}\text { Ixodes ricinus } \\
\text { I. pacificus } \\
\text { I. scapularis }\end{array}$ & $\begin{array}{l}\text { Numerous } \\
\text { mammals }\end{array}$ & $\begin{array}{l}\text { Europe, Northern } \\
\text { America, Russia }\end{array}$ \\
\hline Babesioses & $\begin{array}{l}\text { Babesia } \\
\text { divergens, } \\
\text { B. microti, } \\
\text { B. venatorum }\end{array}$ & Ixodes ricinus & $\begin{array}{l}\text { Bovines, rodents, } \\
\text { deer }\end{array}$ & Europe \\
\hline
\end{tabular}

